放射線照射時に発生する溶血性物質に就いて

\author{
第 二 編 \\ 溶血性物質の定性的研究並びに生物作用に就いて \\ 岡山大学医学部放射線医学教室 (主任 : 武田俊光教授) \\ 専攻生 赤木 瑩子 \\ [昭和 35 年 7 月 11 日受稿]
}

\begin{abstract}
楮論

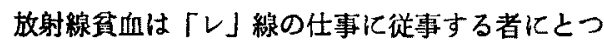
ても宿命的な存在と考えられていたが，余り世人の 関心を惹起することなく看過されていたが，第二次 大戦以来核兵器の発明及び原子核エネルギーの平和 的利用に伴い渐くにして放射線血液障害は世人の関 心を意起し，これが原因に関する研究も多く行なわ れて来た。然し未だ放射線生物作用機転の本態関 する研究は少なく，唯だ Lea1)，Banon2) 等の酸化 説が見られるか，てれのみにてはその血液障害の本 態の解明は困難である。一方放射線血液障害を生化 学的方面の実呀より追及するに障害が発生してくる と血清鉄の增加，網内系組織への〔へモデデリン」 の沈着が起るとと，或は血球の抵抗性の低下等放射 線血液障害は溶血性負血たる事を推定させる，又放 射線炤射時に溶血性燐脂啠の発生する事を既に教室 の山本は報告しているか，私は第一編で斯る物军の 各組織に与える影整について報告し，本編に於ては 斯る抽出物質の本態化つき「ペーパークロマトグラ フ」により追及すると共に各線量を琞射せる家鬼よ りの抽出竐物質の签血度, バフンゥ二の䀦割に及は す影霎につき調査し之を報告せんとするるのである．
\end{abstract}

\section{実 臨 方 法}

\section{1) 抽出法}

健康家克にそれぞれ $3,000 \mathrm{r}, 2,000 \mathrm{r}, 1,000 \mathrm{r}$, $500 \mathrm{r}$ を照射しをれ等各照射群之非照射群の 5 群 に分与照射群は各線量照射後24时到目に山助死せし め、その肝筒を「ホモゲナイザー」で細磁し急速に $80^{\circ} \mathrm{C}$ 乾熱堿菌器中に入れて乾燥し，てれを更に細 确し，乾燥末 $10 \mathrm{~g}$ を10倍量の「純エタノール」中

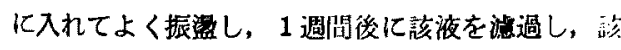
滤液を更に溜去し，残渣を「不油エーテル」で溶解
し溶液を漗置し，更に残渣を「エーテル」に溶解し， これに更に「アセトン」を加え沈漵物を採り急速に 乾燥し，これを用に䠦み使用する事にした。

\section{2) 試料作製}

溶血試験用には上記の物質を隇菌生理的食塩水 に溶解す. 溶解の方法としては $3,000 \mathrm{r}, 2,000 \mathrm{r}$, $1,000 \mathrm{r}, 500 \mathrm{r}$ と非照射群の各家兔肝乾燥末 $10 \mathrm{~g}$ を抽出用材料に使用し，最終抽出物質量の如何に拘 わらず凡ての群を $40 \mathrm{cc}$ の隇菌生理的食塩水汇溶解 する事にした（これは本実験に於ては放射線照射に よる生物的効果の実験なるため同一重量の家鬼肝に 照射し，そこに産生された溶血性物犋と非照射の家 鬼肝との間に差が存在するるのと推定したためであ る).

上記の如き溶解液を原液として $3,000 \mathrm{r}, 2,000 \mathrm{r}$, $1,000 \mathrm{r}, 500 \mathrm{r}$ と非照射群の各群について作製しこ れを使用した。

\section{3）溶血試験}

溶血試験は法の如く $1 \%$ 血球浮游減菌生理的食塩 水を作製し，乙れを各溶血試験管に $1 \mathrm{cc}$ 宛分注して れに各群の10，100，200，400，800，1，000，2,000， $4,000,8,000,10,000,20,000$ 倍の稀採液 $1 \mathrm{cc}$ 宛を 注入し, 後よく湿合しこれを $38^{\circ} \mathrm{C}$ 啲莭器の中に2 時間入れ時々振㗐し，それを取り出しハンドスペク ターにて溶血の有算を調へた。.

\section{4）馬蕫ウニの卵割に及ほす影零について}

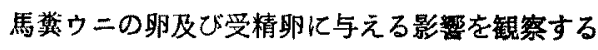
ために次のような方法で実験を実施した，材料に注 阔山県芭久郡虫明海岸で採取した「バフンウニ」を 使用した．次いで畉細胞に与える本物質の作用を観 察するために未受精眨を $0.01 〜 0.02 \%$ の本物質で 30 分間処理し（処理後は正常海水にて 2 回洗涤した） 正常精子の助精による受精膜形成率を助精後 3 分に て「ブアン」氏液で固定し観察した. 贸割率は助精後 
100分にて「ブアン」氏液にて固定し観察した，次

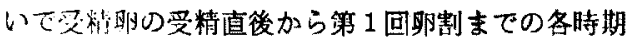
に於汁る体物質に対する感受性を観察するため江受 精後 6 分, 20 分， 40 分， 80 分， 90 分， 100 分飞 0.06

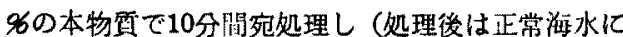
て2回沉濑した）次いで受精後100分後に「ブアン」 氏液で固定し钼察した．次いで観察湘定は500 個の 細胞について行い測定值は百分率で示しにた。

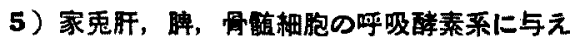

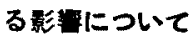

この実験のために前記各線量照射家鬼肝より抽山 した体物行の溶解波の 2 婂，10倍，100倍，1，000倍

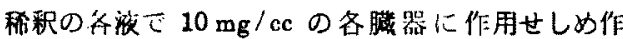
用直後 1，3 時問処理した時に示すコハ夕酸脱水装

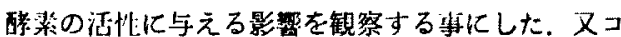

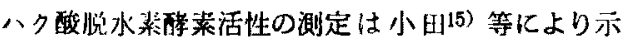
された方法に従つた。

6）ペーパークロマトケラフィーによる試料 の定性について

ペーパークロマトグラフィーについては出々の溶 剂で展開されているが Huennkeno \& Hanahan ${ }^{3)}$ 等 はブタノール: 水 $(8: 1)$, エタノール: 水 $(8: 1)$,

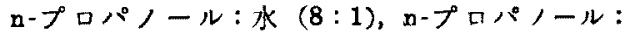

醋酸：水 (8:1:1) で行ないR.F. Wister G.V4) Marinetti 等は 2-Pentanone acetic acid $(30: 2)$, 3-Methyl-2-butanone-acetic acid (30:3), 4Methyl-2-Pentanone-acetic acid (30:2), 2,6Dimethyl-4-hepta/one-acetic acid (30:7) 等で行 つているが，私は入手容易なエタノール：水で行つ t.

\section{実 殹 結 果}

\section{1. 楁血試倹の結果}

法の如く行なつた溶血試験の結果は第 1 表の如く であり，大体「レ」線量に比例している如き成績が 得られた。

\section{2. 馬菜ウニ眆に与える影需にコいて}

畉細胞に与える本物質の作用について見るに本物 䝯にて30分間処理した师（正常精子の助精による） は受精膜形成率に全く変化を受けず热処理群と差を 認めないが卵割率は，その濃度の上昇と平行して低 下する。

卵割率の低下は卵割の阻害ではなく 130 分後には 殆んど総ての処理群で期割率が98\%に近い值を示す。 この事は卵割晕延を来した事の結果と考える。
第 1 表 溶 血試験 結果

\begin{tabular}{|c|c|c|c|c|c|}
\hline & 踌琞 & \begin{tabular}{|c|}
$500 \mathrm{r}$ \\
照射群
\end{tabular} & $\begin{array}{l}1000 \mathrm{r} \\
\text { 照射辟 }\end{array}$ & $2000 \mathrm{r}$ & $\begin{array}{c}\overline{3000 \mathrm{r}} \\
\text { 照射群 }\end{array}$ \\
\hline \multirow{5}{*}{$\mathrm{X} 10$} & + & + & + & + & + \\
\hline & + & + & + & + & + \\
\hline & + & + & + & + & + \\
\hline & + & + & + & + & + \\
\hline & + & + & + & + & + \\
\hline 平均 做 & + & + & + & + & + \\
\hline \multirow{5}{*}{$\times 100$} & + & + & + & + & + \\
\hline & + & + & + & + & + \\
\hline & + & + & + & + & + \\
\hline & + & + & + & + & + \\
\hline & + & + & + & + & + \\
\hline 均 值 & + & + & + & + & + \\
\hline \multirow{5}{*}{$\times 200$} & + & + & + & + & + \\
\hline & + & + & + & + & + \\
\hline & + & + & + & + & + \\
\hline & + & + & + & + & + \\
\hline & + & + & + & + & + \\
\hline 平均 值 & + & + & + & + & + \\
\hline \multirow{5}{*}{$\mathrm{X} 400$} & + & + & + & + & + \\
\hline & + & + & + & + & + \\
\hline & + & + & + & + & + \\
\hline & + & + & + & + & + \\
\hline & + & + & + & + & + \\
\hline 平 均 值 & + & + & + & + & + \\
\hline \multirow{5}{*}{$\mathrm{x} 800$} & + & + & + & + & + \\
\hline & + & + & + & + & + \\
\hline & + & + & + & + & + \\
\hline & + & + & + & + & + \\
\hline & + & + & + & + & + \\
\hline 平 均 值 & + & + & + & + & + \\
\hline \multirow{5}{*}{$\mathrm{X} 1000$} & + & + & + & + & + \\
\hline & + & + & + & + & + \\
\hline & + & + & + & + & + \\
\hline & \pm & + & + & + & + \\
\hline & + & + & + & + & + \\
\hline 平 均 值 & + & + & + & + & + \\
\hline \multirow{5}{*}{$\mathrm{X} 2000$} & \pm & \pm & + & + & + \\
\hline & \pm & + & + & + & + \\
\hline & - & \pm & + & + & + \\
\hline & - & + & + & + & + \\
\hline & - & \pm & + & + & + \\
\hline
\end{tabular}




\begin{tabular}{|c|c|c|c|c|c|}
\hline 平 均 值 & - & \pm & + & + & + \\
\hline$\times 4000$ & $\begin{array}{l}- \\
- \\
- \\
- \\
-\end{array}$ & $\begin{array}{l}- \\
- \\
- \\
-\end{array}$ & $\begin{array}{l} \pm \\
\pm \\
\pm \\
+ \\
+\end{array}$ & $\begin{array}{l} \pm \\
\pm \\
+ \\
+ \\
+\end{array}$ & $\begin{array}{l}+ \\
+ \\
+ \\
+ \\
+\end{array}$ \\
\hline 平 均 值 & - & - & \pm & + & + \\
\hline X8000 & $\begin{array}{l}- \\
- \\
- \\
-\end{array}$ & $\begin{array}{l}- \\
- \\
- \\
-\end{array}$ & $\begin{array}{l}- \\
- \\
- \\
-\end{array}$ & $\begin{array}{l} \pm \\
\pm \\
\pm \\
\pm \\
+\end{array}$ & $\begin{array}{l}+ \\
+ \\
+ \\
+ \\
+\end{array}$ \\
\hline 平均 值 & - & - & - & \pm & + \\
\hline X 10000 & $\begin{array}{l}- \\
- \\
- \\
-\end{array}$ & $\begin{array}{l}- \\
- \\
- \\
-\end{array}$ & $\begin{array}{l}- \\
- \\
- \\
-\end{array}$ & $\begin{array}{l}- \\
- \\
- \\
- \\
-\end{array}$ & $\begin{array}{l}- \\
\pm \\
\pm \\
- \\
\pm\end{array}$ \\
\hline 平均 值 & - & - & - & - & \pm \\
\hline
\end{tabular}

受精卵の各時期に於ける本物質に対する感受性の 成績について見るに受精直後に僅汃の感受性を示し Metophase 加ら後の Anaphase Telophase に於て 最も高い感受性を示す. 然しその最も高い感受性を 示す Telaphase に於てす僅かに30\%6程度の卵制低 下に過ぎい。

ペーパークロマトグラフィーの結果についてみる

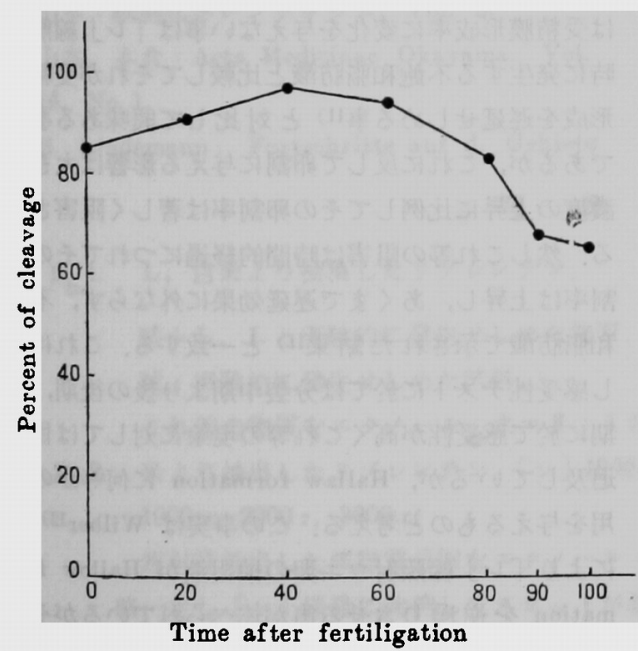

正常卵及び精子を受精せしめ種々の時間で $0.05 \%$ のリソレンチンを10分間作用せしぬ 110 分後に卵割 した紐胞数を\%にて示した物

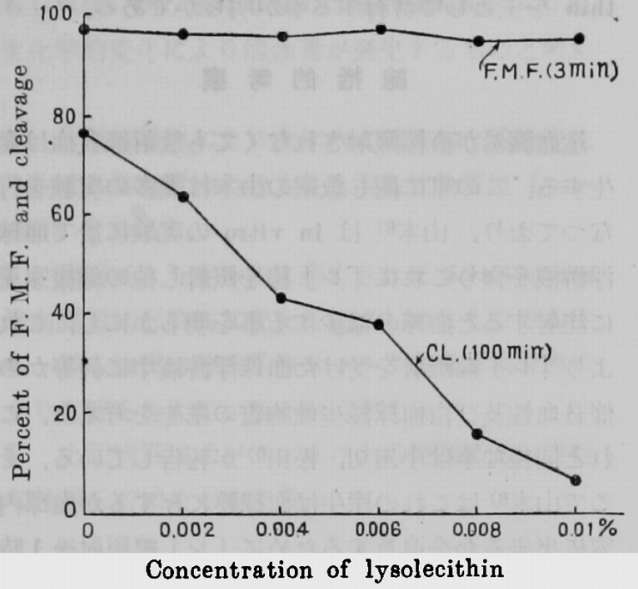

受精前に 30 分間種々涶度のリソンンチン $(0.002$ 〜0.019）を卵飞作用せしめ後正常 Spem とて助精 乙 3 分後 (F.M.F. $3 \mathrm{~mm}$ ) 受精膜形成卵の\%を求め た物及び100分後に 2 分割した卵の名にて示した物

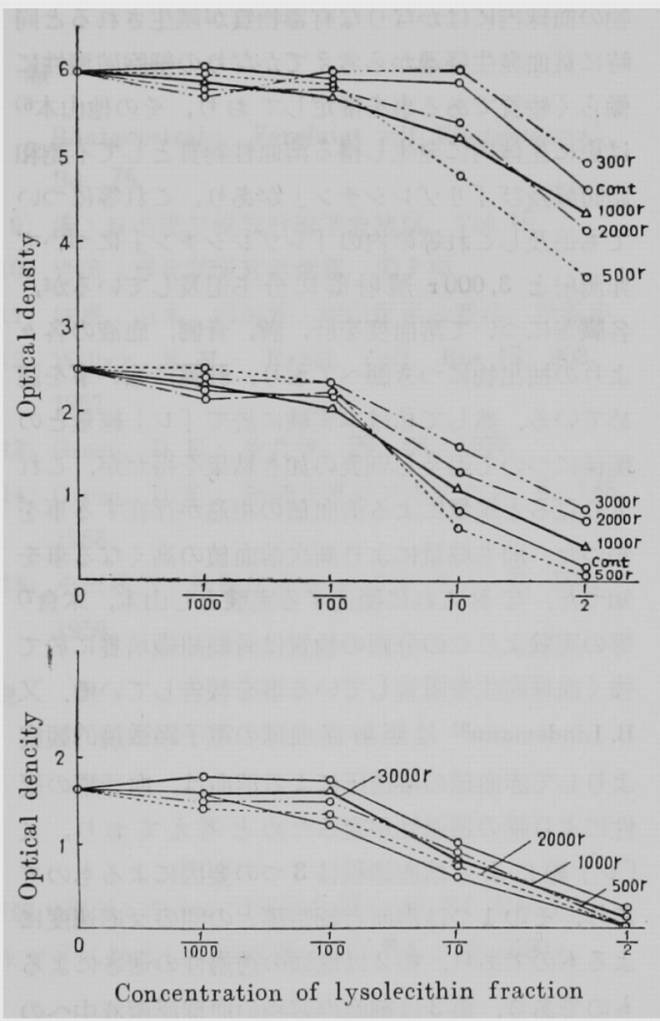

にこれについては白米より抽出した Lysolecithin も同様にペーパークロフトグラフィーで展開すると Huennkenos \& Hanahan の如 $く$ Rf 0.89 近くの值を 示した．他の「レ」線照射後抽出せるものも同一の滤 紙で展開すると同一の Rf を示す矛より Lysoleci- 
thin を主として含有する可が明らかである。

\section{総括 的考察}

造血搭器が值接服射されなくても放射線貫血は発 生する。この事関し教室の山本は绒多の実験を行 なつており，山本6)は in vitro の実験に於て血球 浮游液を作りとれに「レ」線を照射し他の揵康家鬼 に注射すると血球の減少する事を明らかにし，乙れ より「レ」線照射を受りた血球浮游液中に何等かの 催貫血性及び白血球減少性物窴の産生を考えた。と れと同様な事は小田切，松田ら)が報告している，そ こで山本6)はこれの産生は血球膜に存するか血球内 容に出来るかを追及するために「レ」楾照射後 1 時 間 $37^{\circ} \mathrm{C}$ の睬卵器内に保存した後に蒸溜水により溶 血せしめ，その上清と沈没物とに分けたるすのを各 々健康家鬼に注射せるに上清の部分にかなり顕著な る作用が認められる点より「レ」線照射を受けた動 物の血球内にはかなりな有毒物質が産生されると同 特に貧血発生释過から考えてかなりの稩胞破罗性に 墈らく物質である事を推定しており，ての他山本 ${ }^{6)}$ は更に生体內に発生し得る溶血性物兵として不飽和 脂肪酸及び「リソンシチン」があり，とれ等につい ても追及しとれ等の内の「レゾレシンンについて 非照射と 3,000 r 照射群に分ち追及しているか， 各葴器について溶血度を肝，睡，骨䯣，血液の各々 よりの抽出物につき調へており，肝䂸に強い事を認 めている. 然して私は本夷験に於て「レ」線量との 関係について追及し別表の如き絬果を得たが，てれ より見ると線量による溶血值の相進が存在する事を 知つた，即ち線量により漸次溶血值の高くなる事を 知つた。なおこれに関連する実験とし山本，本倉7) 等の実験よりこの分画の物賈は骨髄組織培養に於て 強く血球泩生を阻害している事を報告している，又 B. Lindemann ${ }^{8)}$ は照射赤血球の電子顯微鏡的観察 よりして赤血球の渗透圧による溶血は，血球膜の変 性により膜の透過性加変るためと考えており，又 「レ」楾による溶血過程は 3つの要因によるすので あり，その 1 つは溶血上細胞膜との間の反応速度に よるあのであり，第2 は塩類の透過性の速さによる ものであり，第 3 は細胞内容物の血球浮游液中への 融出する速さにより起るとしているとし，その他 Plasma 加存在する時は赤血球膜の「レ」線照射に よる变性により起る溶血は間接的な影整と考える之 いつている，又湊9（は人間の赤血球生食塩浮游液に ついて $1 \times 10^{4} \mathrm{r} \sim 5 \times 10^{5} \mathrm{r}$ 照射の場合に或る時間後
に溶血が起るとし，線量が大なるにつれて溶血現象 は早く，かつ高度に起る，又各線量に於て 2 倍から 100倍稀积の間で明らかに濃度效果か認められ100倍 稀釈赤血球生食塩浮游液中の酸素を除去した場合に は溶血現象は起り難い，in vitroに於㚈る「レ」線 濯血现象は閒接作用により起るもの之推定している。 然しこの場合の照射量は余りにる大量にして夷際の 治潦の場合之少し趣を巽にして我々の考えている点 とは異なる如く考える。

「リゾレシチン」の生理作用について見るに岩 田10)によると $0.02 \sim 0.1 \mathrm{~g}$ の結晶を水に溶解して 鳩に筋肉内注射するとその局部は浮腄を生し後に激 しい楼煘索生ず. 又注射後 $3 \sim 4$ 時間にして激しい 下峲を起し続いて緑色の荥を排泄する，この緑色の 㥿は遊離脂肪酸を注射した時に現われる現象である か，溶血作用によつて血球が盛んに破填されるため の結果と推定している．0.1 g を二十日聂に注射す る時は注射局所に浮腫を生じ 3 12時閒にて大部分

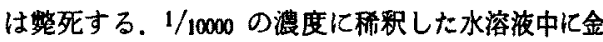
魯を放てば「サポニン」類汇特有の現象即ち全身よ り白色の粘洨を分泌しつつ半時間加 1 時間位の間に 整死する. 又体重 $1,500 \mathrm{~g}$ の家患に $1 \mathrm{cc}(9.5 \%$ 溶 波）を注射すると $6 \sim 7$ 時間軽度の湱眠状態加続く といい, 又体重 $323 \mathrm{~g}$ の樢江 $1 \mathrm{cc}$ (396溶液)を経 口的に与えた処が最初の便に血液を混じ後に緑便に 変る，下籁は起さず翌日の体重 $291 \mathrm{~g}$ となり，程 口的にも幾許かの害を示すという。

先ず卵細片代刘する影然について観察された結果 は受精膜形成率に変化を与えない事は「レ」線照射 洔に発生する不飽和脂肪酸と比校してそれが受精膜 形成を荤延せしめる事(1) と対比して興味ある事実 であるか，これに反して卵割に与える影製は大きく 溜度の上昇に比例してその畉割率は著しく阻害され る. 然してれ等の阻害は時間的経過につれてその卯 制澵は上昇し，あくまで遅延效果に外ならず，不蚫 和脂肪酸で示された結果11) と一致する。これに対 し感受性テストに於ては分裂中期上り後の後期，末 期に於て感受性加高くこれ等の現象に対しては目下 追及しているか， Hallaw formation 化何等加の作 用を与えるすのと考える。（ての事実は Wilber ${ }^{12)}$ 等 により「レ」線照射ウ二卵の抽出液加 Hallow formation を逆戻りさせる事が述へられているがその 要因となるものかるしれない.

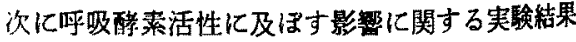
では「レ」綠非照射対㖹群と照射样の間仪照射量の 
增加によつて呼吸醇菜活性阻害の度合が低下する倾 向を示すが，必ずしあ一定の関係を示さない，唯だ 程度の増加により何れの実験群に於てあ呼吸醭素活 性の低下が示されるのは Mitochondria に局在する 醉素がその二重膜䊤造を維持している間のみ電子伝 達が行はわれる事(13) と，その Mitochondria の二 重膜構造が Lipoprotein の一定配列により成立して いる事14)功れ等の構造が「リゾレシチン」分 画の如き脂質に溶解する作用のある物犋で, 二重膜 楆造の崩壊があたらされる可能性が考えられ，従つ て乎吸醭素活珄の阻害結果として現われるものと考 えられる、然してれは単に「リゾレシチン」のみの 作用とは考えられず，その分画に出現する他の Lipoprotein も関係しているものと考えられる. 以上の事加ら私は次の如く考える。

\section{結踚}

1. 放射線資血は物理的現象により一部分は起る

\section{文}

1) Lea, D. E. : Action of Radiation on Living Cells (1947).

2) Barron, E. S. G:J. Gen. physiol 32, 1949.

3) F. M. Hueunkens, D. J. Hanahan, : J. Biol. Chem. 206, 443.

4) R. F. Witter, G. V. Marinetti, : Archives of Biochemistry and Biophysic, Vol. 68, No. 1.

5）小田切, 松田: 未発表.

6) 山本：細胞化学ンンポシウム, Vol. 9.

7) 山本, 本倉 : Acta Medicinae Orayama. Vol. 14, No. 1.

8) B. Lindemann: Fortschritte auf d. Gehiete

かるしれないが，主たる手の放射線照射により起 る生化学的变化により溶血素加発生するすのと考え 万.

2. 放射線照射により生体内に起る生化学的変化 より生ずる燐脂質中の強力なる溶血性物盆は Lysolecithin 亡考える.

3. 照射により生体内に座生された Lysolecithin は造血䑏器に形態的な变化を起さしめるものである。

4. 斯る物質は呼吸系酵素コハク酸脱水素酵素に は余り影響を与えていない如く考える。

5. 上記物䡠は「バフンウニ」の卵割に対し遮延 的な作用を有するものである。

稿を終るに当り恩隔武田俊光教授，我研山本教授， 内海助教授の御指荅御鞭涟を頂いた事に対し深甚の 謝意を表します。

献

Röntgenstrahl. Vereinigt mit Röntgenpraxi. Bd. 75.

9) : 日本医学校放射線学会雑誌, Vol. 16.

10) 岩田: 理化学研究所集報, 第 9 輯.

11）妹尾，山本，内海外：岡山医学会雑誌，投稿中.

12) Wilber, K. M. : Exptl. Cell. Res 13, 903, 1957.

13) Green, D. E. . 生化学, 29, 65, 1957.

14) Green，D. E. : 細胞化学レンポジム，8，145, 1958.

15）小田琢三、細胞化学ンンボジム, 8, 157, 1958.

\section{写真锐明}

写真 1. L，白米より抽出したリソ゚レチン。

試 $+\mathrm{L} ， \mathbf{L}$ と実験的に発生せしめた物質。

試，実験的に発生世しめた試料。

これ等の物質をエタノール：水=8 1 の溶媒で展開したもので何れも同一のRfを示す。

字 真 2. 米より抽出したリソンンチン，「レ」線照射をせずに抽出した燐脂質分画「「」線 $(500 \mathrm{r}$, $1000 \mathrm{r}, 2000 \mathrm{r}, 3000 \mathrm{r}$ )

照射後抽出した燐脂質分画をエタノール：水=8 1 の溶媒にて展用したもの，何れるRf 略一定し「レ」線量飞比例してスポットが濃いのが示されている. 


\title{
Studies on the Hemolytic Substance Produced at X-Ray Irradiation
}

\section{Part 2. Qualitative Analysis and Biological Action of the Hemolytic Substance}

\author{
By \\ EIKO AKAGI \\ Department of Radiation Medicine Okayama University Medical School \\ (Director: Prof. Toshimitsu Takeda)
}

The cause of irradiation anemia seems to lie in biological phenomena as well as in hemolytic toxin produced by X-Ray irradiation. It has been confirmed that since phospholipid fraction in vivo shows strong toxicity in direct proportion to the dose of X-rays, the actual hemolytic substance is lysolecithin. This substance is proved to give rise to marked morphological changes in hematopoietic organs, and it has also been clarified that the same substance acting on sea-urchin egg brings about a delay in egg civision. However the same snbstance does not induce any striking change in the respiratory enzyme system. 
赤木論文附図

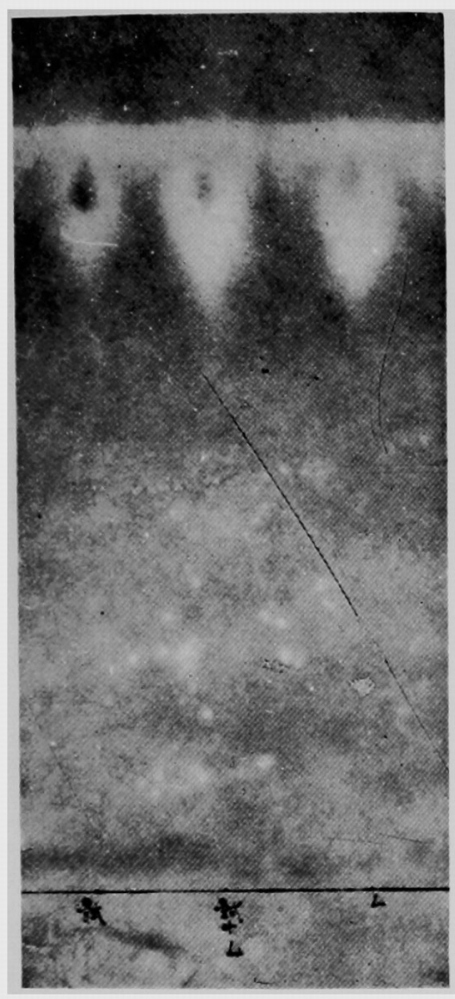

真 1

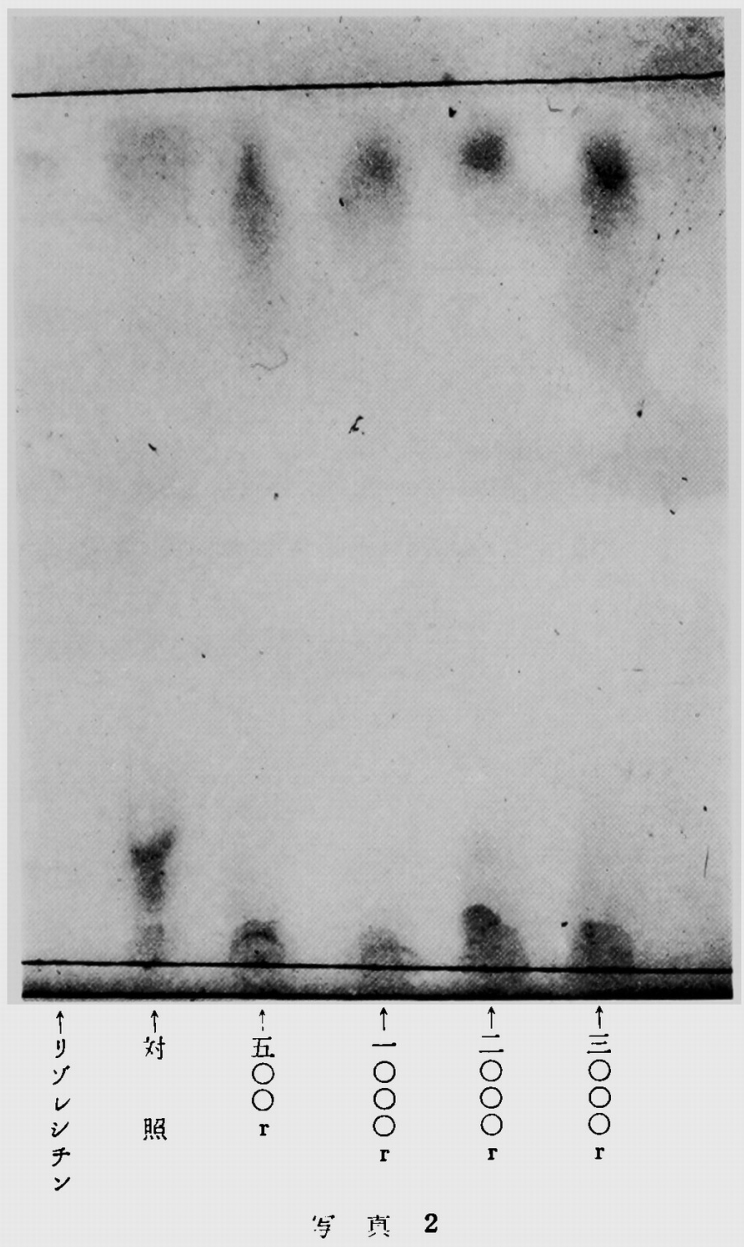

